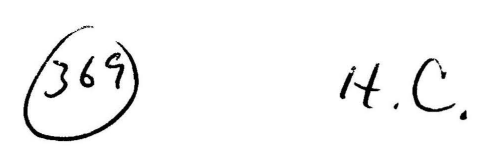

HEMOGLOBIN, 2(6), 513-529 (1978)

\title{
$\delta \beta$-THALASSEMIA IN A MEXICAN FAMILY: CLINICAL DIFFERENCES AMONG HOMOZYGOTES
}

Guillermo Ruiz Reyes

Laboratories Clinicos de Puebla, Puebla, Pue, Mexico

Arturo Piña-Camara

Hospital del Issste, Tuxtla Gutiérrez, Chis, Mexico

and

A.E. Felice, M.E. Gravely, and T.H.J. Huisman

Departments of Cell and Molecular Biology and Medicine

Medical College of Georgia and

Veterans Administration Hospital

Augusta, GA, USA 30901

\section{$\underline{\text { ABSTRACT }}$}

Three $\delta \beta$-thalassemia homozygotes were found in a Mexican family. Both parents and two siblings had heterozygous $\delta \beta-$ thalassemia with about $10 \% \mathrm{Hb}$ F, mild microcytosis and mild hypochromia, while three siblings were normal. Hb F, which was the only $\mathrm{Hb}$ component in the homozygotes, had equal quantities

${ }^{3} \gamma$ and $A_{\gamma}$ chains as in $G_{\gamma} A_{\gamma}-\delta \beta$-thalassemia. The homozygotes a comparable erythrocytic indices which were about the same as those of the heterozygotes. However, two were clinically and hematologically healthy but the third had a severe chronic hemolytic anemia and a more severe in vitro chain synthesis imbalance than her homozygous sisters. Comparison of these cases with other $G_{\gamma} A_{\gamma}-\delta \beta$-thalassemia homozygotes and with $\mathrm{G}_{\gamma} \mathrm{A} \gamma$ HPFH homozygotes indicates the possibility that the proliferation of $F$-cell precursors may be defective in $\delta \beta$-thalassemia.

Received: October 6, 1978; Accepted: November 27, 1978.

Copyright (C) 1979 by Marcel Dekker, Inc. All Rights Reserved. Neither this work nor any part may be reproduced or transmitted in any form or by any means, electronic or mechanical, including photocopying, microfilming, and recording, or by any information storage and retrieval system, without permission in writing from the publisher. 


\section{INTRODUCTION}

Delta-beta-thalassemia has been observed in patients from different racial and ethnic backgrounds but has mainly been described in persons of Mediterranean origin, such as Italians, Greeks, Yugoslavs, Turks, etc. $(1,2,3,4,5,6,7,8)$. The homozygous condition often presents itself as a thalassemia intermedia, and is among others characterized by the complete absence of $\mathrm{Hb} \mathrm{A}$ and $\mathrm{Hb} \mathrm{A}_{2}$, thus having only $\mathrm{Hb} \mathrm{F}$. Recent studies have suggested that the basic defect of the condition is the deletion of the $\delta$ and $\beta$ structural genes (9).

The $\mathrm{Hb} F$ of this type of $\delta \beta$-thalassemia contains two types of $\gamma$ chains: the $G_{\gamma}$ chains (with glycine in position 136) and $A_{\gamma}$ chains (with alanine in position 136) are present in a ratio of about 0.4 to $0.6(10)$. A different form of $\delta \beta$-thalassemia has been found in Blacks, which is characterized by the production of G $\gamma$ chains only (11). A similar condition has been observed in a Chinese family (12). Combinations of both types of $\delta \beta$-thalassen... with $\beta^{0}$ - or $\beta^{+}$-thalassemia have been described $(5,6,11)$.

This communication contains the first report of the $\delta \beta$-tha1assemia condition (G $\gamma$ A $\gamma$-type) in a Mexican family. The homozygous form of this disease expresses itself differently among members of this family. Comparison of the hematological status of G $\gamma A_{\gamma}$ $\delta \beta$-thalassemia homozygotes and $\mathrm{G}_{\gamma} \mathrm{A} \gamma-\mathrm{HPFH}$ homozygotes suggests that there may be a proliferation defect of an F-cell precursor in $\delta \beta-$ thalassemia. 


\section{MATERIALS AND METHODS}

Blood samples. These were collected in vacutainers with EDTA as anticoagulant, and were studied either locally or shipped in ice to Augusta, GA, airmail special delivery.

Hematological analyses. These were made with standard procedures, using a Coulter cell counter. The distribution of $\mathrm{Hb} \mathrm{F}$ containing red cells (F-cells) was evaluated with the method of Kleihauer et al. (13).

Hemoglobin analyses. The hemoglobins in red cell lysates were analyzed by starch gel-, cellulose acetate-, and citrate agar gel electrophoresis (for ref. see 14). Quantification of the hemoglobins was made by DEAE-cellulose chromatography (15), and by an alkali denaturation procedure (16). The $\mathrm{Hb} F$ of the three homozygotes was analyzed by the method of Schroeder et al. (17) to determine the ratio of the $G_{\gamma}$ and $A_{\gamma}$ chains, and by the procedure of Huisman et al. (18) to evaluate the possible presence of $\gamma$ chains with a ..reonyl residue in position 75 instead of an isoleucyl residue. Biosynthetic analyses. Freshly collected blood samples from eight members of this family were incubated with ${ }^{14} \mathrm{C}$-leucine at the local medical facility following the procedure described in detail before (14). Washed red cells were sent in ice, airmail special delivery, to Augusta, GA. Globins from whole red cell lysates were prepared by the method of Anson and Mirsky (19) and analyzed as described (14). 


\section{RESULTS}

Description of the family. The proposita is a six-year-old girl from Tuxtla, Gutiérrez, Chiapas, a city near the MexicanGuatemalan border. The parents observed pale-yellow conjunctiva at the age of 18 months, and facial edema, cephalalgia, asthenia, and adynamia when she was 4 years old. One year later, one of us (G.R.R.) attended to this child and observed palpable lymph nodes, an enlarged liver and spleen, 5 and $13 \mathrm{~cm}$ below the costal margin, respectively, and severe anemia. The patient was treated with several blood transfusions and was reexamined one year later. At that time a further enlargement of the spleen and a functional heart murmur were noted. Hematological data for this patient (Case II-11) are listed in Table I.

The pedigree is given in Fig. 1. The mother has a negroid appearance and the father is known to have Greek ancestors, while both have also a Mexican-Indian ancestry. Nine of the eleven children are living; one son (II-10) died at the age of six as a result of a severe hemolytic anemia which through laboratory and autopsy data was identified as thalassemia major, while one daughter (II-12) died at the age of 8 days due to "congenital cardiopathy". One son (II-4) was unavailable for study. Of the remaining eight children, three (II-2, II-7, and the proposita II-11) appear to have a homozygosity for the thalassemia condition, two (II-1, and II-5) are heterozygous, and three (II-6, II-8, and II-9) are normal. The daughter of II-2 also has the heterozygous condition. The two homozygous daughters II-2 and II-7 are clinically normal without hepatosplenomegaly. 


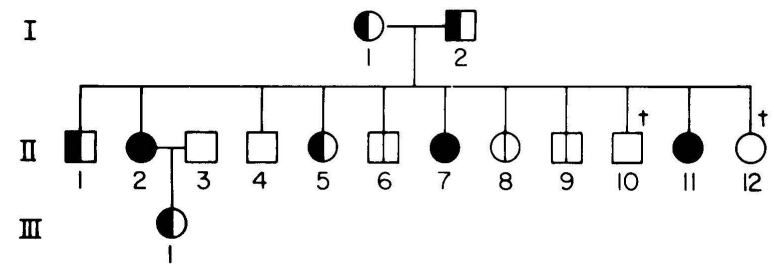

Figure 1: Pedigree of family $P$. with $G_{\gamma} A_{\gamma}-\delta \beta$-thalassemia.

Hematological studies. Data on all available members of this family are listed in Table I. No striking anemia is present except in the proposita. The heterozygous members of this family have a mild microcytosis (MCV values between 77 and $84 \mathrm{fl}$ ) with slight anisocytosis and a mild reticulocytosis while the three normal members are normocytic and normochromic. Cases II-2 and II-7 with the homozygous condition are about comparable to the heterozygous relatives although target cells and poikilocytosis we demonstrable in their blood smears. The blood smear of the proposita, however, is marked by severe poikilocytosis and anisocytosis, by target cells and polychromasia, fragments of cells, teardrop cells and even spherocytes. The picture of Fig. 2 compares the blood smears of Case II-7 with the mild disease and II-11 with the severe disease. F-cells were readily determined in the blood of all heterozygotes and in the three homozygotes, but were absent in the normal members. The proposita had a marked reticulocytosis.

Hemoglobin analyses. Data are listed in Table II. The level of $\mathrm{Hb} \mathrm{F}$ in the heterozygotes averaged $10.5 \%$ without major 
TABLE I HEMATOLOGICAL DATA ${ }^{a}$

\begin{tabular}{|c|c|c|c|c|c|c|c|c|c|c|}
\hline Case $^{b}$ & $\begin{array}{l}\text { Sex and } \\
\text { Age }\end{array}$ & Condition ${ }^{c}$ & $\begin{array}{l}\mathrm{Hb} \\
\mathrm{g} \%\end{array}$ & $\begin{array}{l}\text { PCV } \\
1 / 1\end{array}$ & $\begin{array}{l}\mathrm{RBC} \\
10^{12} / 1\end{array}$ & $\begin{array}{l}\mathrm{MCV} \\
\mathrm{f} 1\end{array}$ & $\begin{array}{l}\mathrm{MCH} \\
\mathrm{pg}\end{array}$ & $\begin{array}{l}\mathrm{MCHC} \\
\mathrm{g} / \mathrm{d} 1\end{array}$ & $\begin{array}{c}\text { Retics } \\
\%\end{array}$ & $\begin{array}{c}\text { F-cells } \\
\text { Distributiond }\end{array}$ \\
\hline \multirow[t]{2}{*}{ I- 1} & $F-46$ & $\mathrm{AF}$ & 12.0 & 0.35 & 4.53 & 77 & & 34 & 1.7 & \\
\hline & & & 13.4 & 0.429 & 5.47 & 80 & 24.7 & 31.1 & & Unequal \\
\hline \multirow[t]{2}{*}{$I-2$} & $M-50$ & $\mathrm{AF}$ & 14.9 & 0.48 & 5.71 & 84 & & 31 & 1.9 & \\
\hline & & & 16.5 & 0.523 & 6.39 & 83 & 25.9 & 31.3 & & Unequal \\
\hline \multirow[t]{2}{*}{ II - 1} & M-27 & $\mathrm{AF}$ & 15.0 & 0.48 & 5.89 & 81 & & 31 & 3.2 & \\
\hline & & & 16.6 & 0.506 & 6.73 & 77 & 24.8 & 32.6 & & Unequal \\
\hline \multirow[t]{3}{*}{ II -2} & F-26 & $\mathrm{FF}$ & 13.3 & 0.39 & 4.66 & 83 & & 34 & 1.5 & \\
\hline & & & 14.5 & 0.405 & 5.09 & 78 & 27.0 & 35.1 & & Equal \\
\hline & & & 14.5 & 0.441 & 5.25 & 85 & 27.7 & 32.7 & & \\
\hline \multirow[t]{2}{*}{ II - 5} & $F-20$ & $\mathrm{AF}$ & 11.6 & 0.37 & 4.71 & 78 & & 31 & 0.6 & \\
\hline & & & 13.1 & 0.410 & 5.08 & 82 & 25.8 & 31.6 & & Unequal \\
\hline \multirow[t]{2}{*}{ II -6} & $M-18$ & $\mathrm{AA}$ & 14.4 & 0.44 & 5.15 & 85 & & 32 & 1.3 & \\
\hline & & & 16.8 & 0.511 & 5.64 & 92 & 30.0 & 32.8 & & Absent \\
\hline \multirow[t]{3}{*}{ II -7} & F-17 & $\mathrm{FF}$ & 11.8 & 0.36 & 4.25 & 84 & & 32 & 2.2 & \\
\hline & & & 12.9 & 0.382 & 4.61 & 81 & 26.6 & 33.2 & & Equal \\
\hline & & & 13.2 & 0.408 & 4.74 & 87 & 28.6 & 32.1 & & \\
\hline \multirow[t]{2}{*}{ II -8} & $F-13$ & $\mathrm{AA}$ & 13.2 & 0.40 & 4.82 & 82 & & 33 & 1.7 & \\
\hline & & & 14.4 & 0.439 & 5.04 & 88 & 28.7 & 32.6 & & Absent \\
\hline \multirow[t]{2}{*}{ II -9 } & M- 12 & $\mathrm{AA}$ & 13.4 & 0.40 & 4.91 & 81 & & 33 & 1.2 & \\
\hline & & & 14.4 & 0.453 & 5.20 & 89 & 27.9 & 31.7 & & Absent \\
\hline \multirow[t]{3}{*}{ II -11} & $F-6$ & $\mathrm{FF}$ & 5.9 & 0.18 & 2.20 & 81 & & 32 & 7.5 & \\
\hline & & & 4.7 & 0.157 & 1.96 & 77 & 22.6 & 28.8 & & Equal \\
\hline & & & 5.2 & 0.187 & 2.24 & 83 & 23.1 & 27.2 & & \\
\hline II I-1 & $F-2$ & $\mathrm{AF}$ & 11.3 & 0.32 & 4.09 & 78 & & 35 & 1.0 & \\
\hline
\end{tabular}

a. The first set of data on each person was obtained in Puebla, Mexico; the second and third sets were obtained in Augusta, GA. using dispatched samples.

b. See pedigree of Figure 1 .

c. $\quad \mathrm{AA}=$ normal $; \quad \mathrm{AF}-\mathrm{A}-\delta \beta$-thal., $\quad \mathrm{F}=\delta \beta$-thal. homozygote.

d. Using the method of Kleihauer et al (13). 
TABLE II

HEMOGLOBIN COMPOSITION AND BIOSYNTHETIC DATA

\begin{tabular}{|c|c|c|c|c|c|c|c|c|}
\hline \multirow[t]{2}{*}{$\operatorname{Case}^{a}$} & \multirow[t]{2}{*}{ Condition $b$} & \multirow{2}{*}{$\mathrm{Hb}_{\%} \mathrm{~A}_{2}{ }^{\mathrm{C}}$} & \multirow{2}{*}{$\mathrm{Hb}_{\%} \mathrm{~A}^{c}$} & \multirow{2}{*}{$\mathrm{Hb} \underset{\%}{\mathrm{~F}} \mathrm{c}$} & \multicolumn{2}{|c|}{$\gamma-C B-3$} & \multirow{2}{*}{\multicolumn{2}{|c|}{$\frac{\alpha}{\gamma+\beta}$ Ratio $^{e}$}} \\
\hline & & & & & Glycine & Alanine & & \\
\hline I-1 & $\mathrm{AF}$ & 2.3 & 88.3 & 9.4 & - & - & & 2.13 \\
\hline $\mathrm{I}-2$ & $\mathrm{AF}$ & 3.2 & 88.0 & 8.8 & - & - & & 1.54 \\
\hline II- 1 & $\mathrm{AF}$ & 2.7 & 85.6 & 11.7 & - & - & & - \\
\hline II-2 & $\mathrm{FF}$ & 0 & 0 & 100 & 0.47 & 2.65 & & 3.33 \\
\hline II -5 & $\mathrm{AF}$ & 2.4 & 85.3 & 12.3 & - & - & & - \\
\hline II -6 & AA & 2.5 & 97.5 & $<1 d$ & - & - & & - \\
\hline II - 7 & $\mathrm{FF}$ & 0 & 0 & 100 & 0.48 & 2.67 & & 3.19 \\
\hline II -8 & $\mathrm{AA}$ & 2.2 & 97.8 & $<1^{d}$ & - & - & & 0.88 \\
\hline II -9 & $\mathrm{AA}$ & 2.4 & 97.6 & $<1 d$ & - & - & & 0.84 \\
\hline II -11 & $\mathrm{FF}$ & 0 & 0 & 100 & 0.53 & 2.51 & & 8.33 \\
\hline
\end{tabular}

a. See Pedigree of Figure 1 .

b. AA: normal; AF: A- $\delta B$-thal.; FF: $\delta \beta$-thal homozygote.

c. By DEAE-cellulose chromatography (15).

d. By alkali denaturation (16).

e. Whole cell globin prepared from red cells, incubated for 120 minutes. 


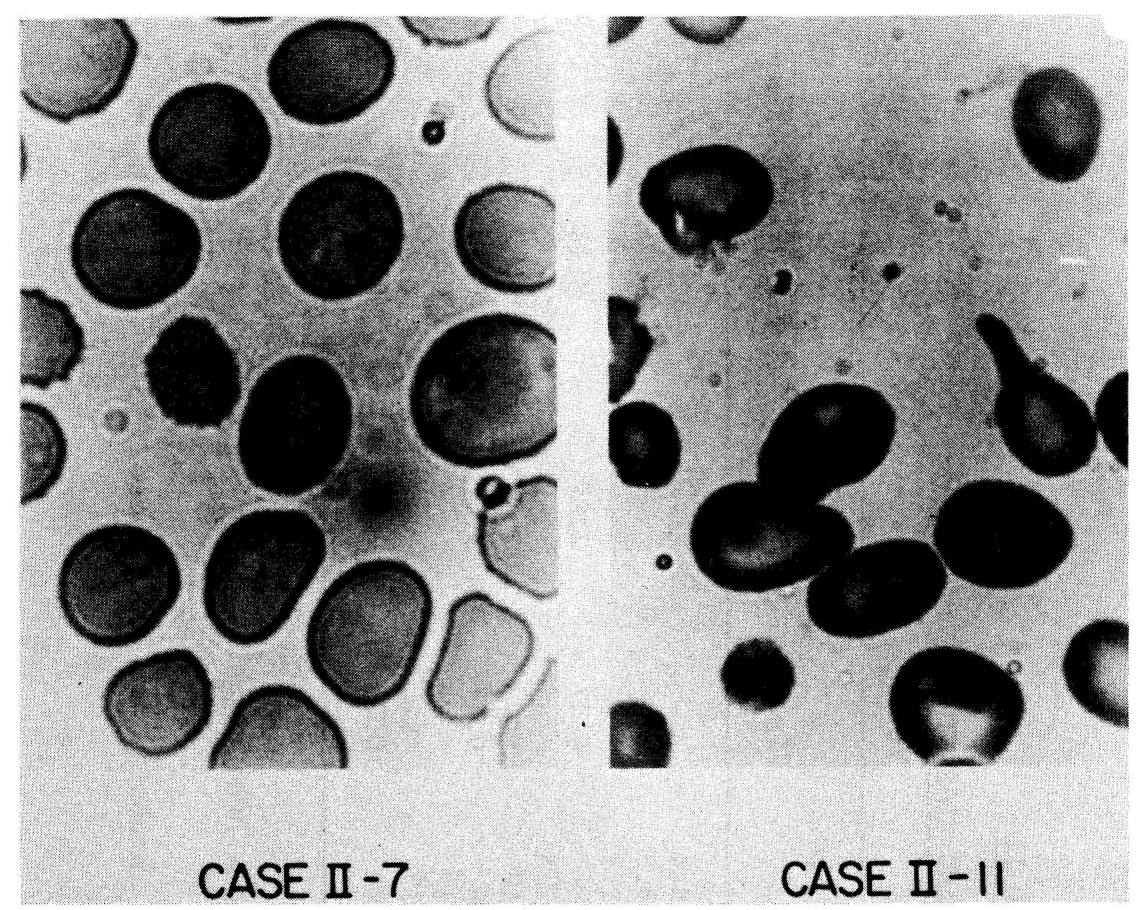

Figure 2: Peripheral blood smears of two $\delta \beta$-thalassemia homozygotes.

individual differences while the average level of $\mathrm{Hb} \mathrm{A}_{2}$ was $2.6 \%$ Cases II-2, II-7, and II-11 had only $\mathrm{Hb} F$ without a trace of $\mathrm{Hb} \mathrm{A}$ or $\mathrm{Hb} \mathrm{A}$. The levels of $\mathrm{Hb} \mathrm{A}_{2}$ and $\mathrm{Hb} \mathrm{F}$ in the three normal members of this family fell within the normal range.

Chemical analysis of the $\mathrm{Hb} F$ was limited to that of the three homozygotes. In all three cases the ratio between the $\mathrm{G}_{\gamma}$ $\mathrm{A}_{\gamma}$ chains averaged 1 being similar to the ratios observed in

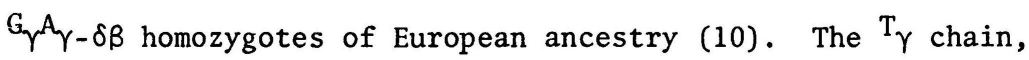


_.e. a $\gamma$ chain with a threony 1 residue in position 75 , was absent in all three patients.

The synthesis data, listed in Table II, indicate a moderate non- $\alpha$ chain deficiency in the three heterozygotes (average $\alpha /$ non- $\alpha$ ratio: 1.86 ), a more striking deficiency in the two homozygotes with a mild disorder (average $\alpha /$ non- $\alpha$ ratio: 3.26 ), and a large deficiency in the proposita with an $\alpha /$ non- $\alpha$ ratio of 8.33 . The average $\alpha /$ non $-\alpha$ ratio of 0.86 in the two normal family members is on the low side of the range of values observed in normal adults in this laboratory (14).

\section{DISCUSSION}

The condition present in this family has all the markings of a $G_{\gamma} A_{\gamma}-\delta \beta$-thalassemia. The heterozygotes have normal levels of $\mathrm{Hb} \mathrm{A}_{2}$ and about $10 \% \mathrm{Hb} \mathrm{F}$ which is unequally distributed among the erythrocytes. The appropriate imbalance in in vitro $\mathrm{Hb}$ chain nthesis is observed, and the glycine value in the $\gamma C B-3$ peptide of the homozygotes is about 0.5 . The erythrocytic indices in the heterozygotes and the homozygotes are similar to those commonly found in other patients with this condition from the Mediterranean littoral. The data from both parents are about the same and one wonders if consanguinity is present (the lower $\alpha /$ non- $\alpha$ ratio in the father (1.54) as compared to that in the mother (2.13) might be coincidental).

The clinical and hematological status of the proposita i.e. severe hemolytic anemia, with marked morphological changes of the erythrocytes, hepatosplenomegaly, bone changes and 
cardiomegaly has persisted for 4 to 5 years and contrasts sharply with those in her two homozygous sisters. The same situation may have also been present in her brother (II-10) who died at the age of six with a similar clinical and hematological syndrome. The studies of her two homozygous sisters and of the three heterozygous relatives fail to offer an explanation for the severity of the disease in Case II-11 compared with Cases II-2 and II-7. There is no reason to assume that the genetic defect is different, but the in vitro chain imbalance is much more severe in Case II-11 than in the other two homozygotes. Both parents appear to be $G_{\gamma} A_{\gamma}-\delta \beta$-thalassemia heterozygotes. The presence of three normal children in this family further indicates that both parental chromosomes in trans to the thalassemia determinant have normal $\gamma, \delta$, and $\beta$ genes. One possible explanation for the observed differences is based on a variable number of active $\alpha$ chain structural genes, and assumes that a relative $\alpha$ chain deficiency due to a limited number of $\alpha$ chain genes is beneficial for $\delta \beta$-thalassemia homozygotes mainly because the excessive production of free $\alpha$ chains is lessened. Cases II-2 and II-7 could be homozygous for $\alpha-$ thalassemia-2 (the $-\alpha /-\alpha$ genic arrangement) while Case II-11 has four active $\alpha$ chain structural loci (the $\alpha \alpha / \alpha \alpha$ genic arrangement) or perhaps an $\alpha$-thalassemia- 2 trait (the $-\alpha / \alpha \alpha$ genic arrangement). This explanation primarily finds support in the differences in $\alpha /$ non- $\alpha$ biosynthetic ratios with the highest value in Case II-11 with the presumed four active $\alpha$ chain 
structural loci. Moreover, decreased free $\alpha$ chain production will lead to decreased red cell hemolysis and less distinct hematological abnormalities. The explanation proposed is difficult to prove without molecular hybridization or restriction endonuclease analyses of hemoglobin genes in cellular DNA. Such an investigation might also prove to be difficult because family members are not readily available for study.

The three $G_{\gamma} A_{\gamma}-\delta \beta$-thalassemia homozygotes described in this communication bring the total number of known cases with this type of condition to 13 in seven families. Their hematological and biochemical features and some limited information on their heterozygous relatives are summarized in Table III. Data on nine ${ }^{\mathrm{G}} \gamma \gamma$-HPFH homozygotes and their heterozygous relatives are also listed in this table. This type of HPFH is the variant of the Hereditary Persistance of Fetal Hemoglobin which is mnst commonly found in American and African Blacks. The $\mathrm{Hb} F$ in heterozygotes amounts to about $30 \%$, is equally distributed among all erythrocytes, and contains about the same percentages of $\mathrm{G}_{\gamma}$ and $A_{\gamma}$ chains. There is a total absence of $\beta^{A}$ chain synthesis in cis $(21,24)$.

A considerable overlap of the erythrocytic indices is present in $\mathrm{G}_{\gamma} \mathrm{A}_{\gamma}-\delta \beta$-thalassemia and $\mathrm{G}_{\gamma} \mathrm{A}_{\gamma-\mathrm{HPFH}}$ homozygotes, but the steady state hemoglobin levels are distinctly lower in the

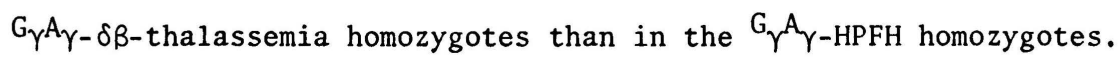
The hematological picture of homozygous $\mathrm{G}_{\gamma} \mathrm{A}_{\gamma-\delta \beta}-$ thalassemia is that of a moderate,we11 compensated, chronic hemolytic anemia. 
TABLE III

HEMATOLOGICAL AND BIOCHEMICAL DATA ON $\mathrm{G}^{\mathrm{A}} \gamma$ - $\delta \beta$-THALASSEMIA AND ${ }^{\mathrm{A}} \gamma^{\mathrm{A}} \gamma$-HPFH HOMOZYGOTES

\begin{tabular}{|c|c|c|c|c|c|c|c|c|c|c|c|c|c|}
\hline & & & Homozygo & us ${ }^{G} \gamma^{A} \gamma-\delta \beta$ & -Thalas & ssemi & & & & & $\begin{array}{l}\text { eteroz } \\
\text { Relati }\end{array}$ & $\begin{array}{l}\text { ygous } \\
\operatorname{ves} a\end{array}$ & \\
\hline $\begin{array}{c}\text { Case } \\
\text { No. }\end{array}$ & Fam. & $\begin{array}{l}\text { Sex- } \\
\text { Age }\end{array}$ & $\begin{array}{c}\text { Country } \\
\text { of } \\
\text { Origin }\end{array}$ & $\begin{array}{c}\text { General } \\
\text { Condition }\end{array}$ & $\begin{array}{l}\mathrm{Hb} \\
\mathrm{g} / \mathrm{d} 1\end{array}$ & $\begin{array}{r}\mathrm{MCV} \\
\mathrm{f} 1\end{array}$ & $\begin{array}{r}\mathrm{MCH} \\
\mathrm{pg}\end{array}$ & $\begin{array}{c}\alpha / \gamma \\
\text { total } \\
\mathrm{cpm}\end{array}$ & $\begin{array}{c}\gamma \mathrm{CB}-3 \\
\mathrm{~g} l \mathrm{y}\end{array}$ & $\begin{array}{l}\mathrm{MCV} \\
\mathrm{f} 1\end{array}$ & $\underset{\%}{\mathrm{Hb} F}$ & $\begin{array}{r}\gamma \mathrm{CB}-3 \\
\mathrm{~g} 1 \mathrm{y}\end{array}$ & Reference \\
\hline $\begin{array}{l}1 . \\
2 . \\
3 . \\
4 . \\
5 . \\
6 . \\
7 . \\
8 . \\
9 . \\
10 . \\
11 . \\
12 . \\
13 .\end{array}$ & $\begin{array}{l}\mathrm{D}^{b} \\
\mathrm{E} \\
\mathrm{F} \\
\mathrm{G}\end{array}$ & $\begin{array}{l}\text { F-31 } \\
\text { F-1 } \\
\text { F-5 } \\
\text { F-3 } \\
\text { M-25 } \\
\text { M-12 } \\
\text { F-9 } \\
\text { M-22 } \\
\text { F-3 } \\
\text { M-6 } \\
\text { F-26 } \\
\text { F-17 } \\
\text { F-6 }\end{array}$ & $\begin{array}{r}\text { Italy } \\
\text { Sicily } \\
\text { Arab } \\
\\
\text { Greece } \\
\text { Turkey } \\
\text { Turkey } \\
\text { Mexico }\end{array}$ & $\begin{array}{l}\text { Good } \\
\text { Good } c \\
\text { Good } \\
\text { Good } \\
\text { Good } d \\
\text { Good }^{e} \\
\text { Good }^{e} \\
\text { Fair } \\
\text { Poor } \\
\text { Fair } \\
\text { Good } \\
\text { Good } \\
\text { Poor }\end{array}$ & $\begin{array}{c}8.7 \\
10.2 \\
12.7 \\
10.0 \\
12.3 \\
\text { nd } \\
\text { nd } \\
9.0 f \\
6.9 \\
9.0 \\
14.1 \\
12.6 \\
5.3^{i}\end{array}$ & $\begin{array}{l}80 \\
68 \\
82 \\
71 \\
85 \\
\text { nd } \\
\text { nd } \\
88 \\
82 \\
85 \\
82 \\
84 \\
80\end{array}$ & $\begin{array}{l}22 \\
20 \\
24 \\
24 \\
25 \\
\text { nd } \\
\text { nd } \\
23 \\
28 \\
25 \\
27 \\
28 \\
23\end{array}$ & $\begin{array}{r}\text { nd } \\
1.4 \\
1.8 \\
\\
\text { nd } \\
\text { nd } \\
\text { nd } \\
\text { nd } \\
3.7 \\
4.9 \\
3.3 \\
3.2 \\
8.3\end{array}$ & $\begin{array}{c}0.49 \\
0.56 \\
\text { nd } \\
\text { nd } \\
0.59 \\
\text { nd } \\
\text { nd } \\
0.53 \\
0.53 \\
\text { nd } \\
0.47 \\
0.48 \\
0.53\end{array}$ & $\begin{array}{l}74 \\
67 \\
78 \\
\\
80\end{array}$ & $\begin{array}{r}10.1 \\
9.0 \\
11.9 \\
4.7 \\
8.2 \\
11.8 \\
10.6\end{array}$ & $\begin{array}{r}\text { nd } \\
0.42 \\
\text { nd } \\
\text { nd } \\
0.37 \\
\text { nd } \\
\text { nd }\end{array}$ & $\begin{array}{l}4,9 \\
20 \\
20 \\
\text { this } \\
\text { paper }\end{array}$ \\
\hline
\end{tabular}




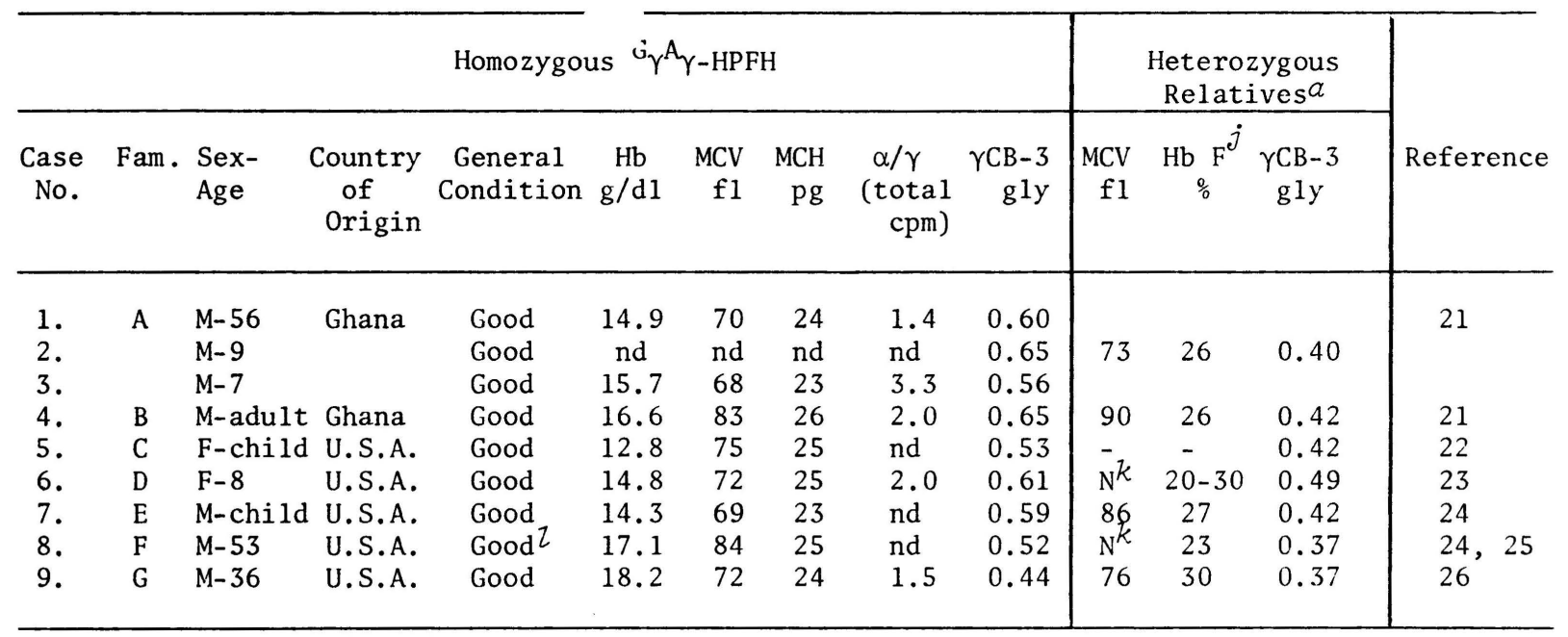

a. Data are averages of 2 or more relatives; no distinction is made between Hb F values determined by different techniques.

b. These are the cases shown by Ottolenghi et al. (9) to have deletion of $\beta$ DNA.

c. General condition poor on admission due to upper respiratory tract infection which resolved without treatment.

d. Severe anemia during febrile episode required blood transfusion.

e. Reported as "No abnormal physical finding"; hematology not given.

f. $\mathrm{Hb} 4.2 \mathrm{~g} / \mathrm{d} 1$ during febrile episode.

g. Hb levels poorly maintained by blood transfusions - Deceased.

$h$. Had hepatitis. Younger sister died with diagnosis of Cooley's anemia.

$i$. Average data. Sibling died with diagnosis of thalassemia major.

$j$. Hb F by DEAE cellulose chromatography (15) varies between 20 and $30 \%$ with about $5-7 \%$ of a mixture of $\mathrm{Hb} \mathrm{A}_{1}+\mathrm{Hb} \mathrm{F} 1$.

$k$. Reported as normochromic and normocytic.

i. Patient was alcoholic with congestive heart failure and gastric ulcer - Deceased. 
However, decompensation resulting in severe anemia occurs rather frequently especially in association with febrile episodes. It should be noted that among the families listed in Table III three deaths have been reported in individuals diagnosed as Cooley's anemia or thalassemia major. Similar occurrences have not been observed in the $\mathrm{G}_{\gamma} \mathrm{A}_{\gamma}$-HPFH homozygotes or their relatives who are clinically and hematologically healthy.

It appears that homozygous $\mathrm{G}_{\gamma} \mathrm{A} \gamma-\delta \beta$-thalassemia is expressed as a thalassemia intermedia because of maximal erythropoietic compensation for the chronic hemolysis. Environmental factors such as infectious disease can result in severe decompensation perhaps because the proliferation of F-cells may be limited in $\mathrm{G}_{\gamma} \mathrm{A}_{\gamma}$ - $\delta \beta$-thalassemia compared to $\mathrm{G}^{\mathrm{A}} \gamma$-HPFH. A selective proliferation of A-cells rather than F-cells would be expected to decrease whole blood $\mathrm{Hb} F$ levels, and indeed the $\mathrm{Hb} F$ level in $\mathrm{G}_{\gamma} \mathrm{A} \gamma$ - $\delta \beta$-thalassemia heterozygotes is about one third that of the $\mathrm{G}_{\gamma} \mathrm{A}_{\gamma-\mathrm{HPFH}}$ heterozygotes (Table III). However, it appears that in $\mathrm{G}_{\gamma} \mathrm{A}_{\gamma-\mathrm{HPFH}}$ heterozygotes, $\gamma$ chains are produced in all erythroblasts while only a subpopulation of $G_{\gamma} A_{\gamma}-\delta \beta$-thalassemia erythroblasts are programmed to produce $\gamma$ chains. Thus, in homozygotes where survival of A erythroblasts is impaired because of $\beta$ gene deletion, only the F-cell progeny mature to completion. The limited proliferation of F-cell precursors in $G_{\gamma} A-\delta \beta$-thalassemia heterozygotes is also observed in the homozygotes, and a small increase in F-cell output as may be required during a concurrent infection cannot be produced 
zcause the precursors may already be maximally stimulated.

Of course, the genetic basis for the proliferative deficiency of the F-cell population in $G_{\gamma} A_{\gamma}-\delta \beta$-thalassemia is not apparent from these considerations.

\section{ACKNOWLEDGEMENTS}

The authors are greatly indebted to the various members of the P. family for their continued cooperation. Also, to Rafael Guerrero García, M.D., Mercedes Sánchez-Fernandez QFB and Norma Landero de Ruiz, QFB, for their technical assistance and valuable help. This research was in part supported by United States Public Health Service Grants HLB-05168 and HLB-15158.

\section{REFERENCES}

1. Brancati, C. and Baglioni, C. 1966. Nature 212: 262.

2. Fessas, Ph. 1968. Proc. XIIth Cong. Int. Soc. Haemat. N.Y., p. 52, Grunne and Stratton, New York.

3. Efremov, G.D., Nickov, N., Duma, N., Schroeder, W.A., Miller, A. and Huisman, T.H.J. 1975. Scand. J. Haematol. 14: 226 .

4. Tsistrakis, G.A., Amarantos, A.P. and Konkouris, L. L. 1974. Acta Haemat. 51: 1852 .

5. Weathera11, D. J. and Clegg, J。B. 1972. The Thalassemia Syndromes. p. 118. Blackwell Scientific Publications, Oxford.

6. Bunn, H.F., Forget, B.G. and Ranney, H. M. 1977. Hemoglobinopathies. W.B. Saunders, Philadelphia.

7. Silvestroni, E., Bianco, I. and Reitano, G. 1968.

Acta Haemat. 40: 220-229. 
8. Ramot, B., Ben-Bassat, I., Gafni, D. and Zaanoon, -R. 1970. Blood 35: 158-165.

9. Ottolenghi, S., Comi, P., Giglioni, B., Tolstoshev, P., Lanyon, W. G., Mitche11, G.J., Williamson, R., Russo, G., Musumeci, S., Schiliro, G., Tsistrakis, G.A., Charache, S., Wood, W. G., Clegg, J. B. and Weathera11, D. J. 1976. Ce11 9: $71-80$.

10. Stamatoyannopoulos, G., Schroeder, W.A., Huisman, T.H.J., Shelton, J.R., Shelton, J. B., Ape11, G. and Bouver, N. 1971. Brit. J. Haemat. 21: 633.

11. Altay, C., Schroeder, W.A., and Huisman, T.H.J. 1977. Am. J. Hematol. 3: 1 .

12. Mann, J.R., MacNeish, A.S., Bannister, D., Clegg, J. B., Wood, W. G. and Weathera11, D. J. 1972. Brit. J. Haemat. 23: 393 .

13. Kleihauer, E., Braun, H. and Betke, K. 1975. Klinische Wochenschrift 35: 635 .

14. Huisman, T.H.J. and Jonxis, J.H.P. 1977. The Hemoglobinopathies: Techniques of Identification, Marcel Dekker, Inc. New York.

15. Abraham, E.C., Reese, A., Stallings, M. and Huisman, T.H.J. 1977. Hemoglobin 1: 27 .

16. Betke, K., Marti, H.R. and Schlicht, I. 1959. Nature 184: 1877.

17. Schroeder, W.A., Huisman, T.H.J., Shelton, J.R., Shelton, J.B. Kleihauer, E.F., Dozy, A.M, and Robberson, B. 1968. Proc. Nat1. Acad. Sci, 60: 537. 
3. Huisman, T.H.J., Schroeder, W.A., Reese, A., Wilson, J.B., Lam, H., She1ton, J.R., Shelton, J.B. and Baker, S. 1977. Ped, Res, 11: 1102 .

19. Anson, K. L. and Mirsky, A.E. 1930. J. Gen. Physiol. 13: 469.

20. Dincol, G., Altay, C., Aksoy, M., Gurgey, A., Felice, A.E. and Huisman, T.H.J. in preparation.

21. Ringe1hann, B., Acquaye, C.T.A., O1dham, J.H., KonoteyAhulu, F.I.D., Yawson, G., Sukumaran, P. K., Schroeder, W.A. and Huisman, T.H.J. 1977. Biochem. Genet. 15: 1083-1096.

22. Alter, B. and Collaborators, personal communication.

23. Forget, B. G., Hillman, D. G., Lazarus, H., Bare11, E. F., Benz, E. J., (jr)., Caskey, C.T., Huisman, T.H.J., Schroeder, W.A. and Housman, D. 1976. Ce11 7: 323-329.

24. Huisman, T.H.J., Schroeder, W.A., Charache, S., Bethlenfalvay, N.C., Bouver, N., Shelton, J.R., Shelton, J.B. and Ape11, G. 1971. New Eng. J. Med. 285: 711-716.

25. Siege1, W., Cox, R., Schroeder, W.A., Huisman, T.H.J., Penner, 0. and Rowley, P. T. 1970. Ann. Int. Med. 72 : $533-536$

26. Felice, A. E. and Huisman, T.H.J. Unpublished data. 